\title{
Aika on yhteistä, vastuu sen käytöstä jaettua - ajanhallinnan verkkovalmennuksen arviointi
}

\author{
Kirsi Yli-Kaitala \& Minna Toivanen
}

Ajanhallinnan historia yltää aikaan ennen ajanlaskun alkua (esim. Aeon \& Aguinis 2017). Kysymys siitä, kuinka käyttää tehokkaasti hyväksi jotakin, joka ei ole aineellista eikä näkyvää, on kiehtonut ihmismieliä pitkään. Samalla nämä ominaisuudet tekevät tästä ainutkertaisesta resurssista yhä vaikeasti hahmotettavan (vrt. Soman 2001).

Työn irtautuminen ajasta ja paikasta, työn ja yksityiselämän sekoittuminen ja kaikille elämänaloille hiipinyt loppumaton valintojen mahdollisuus on nostanut ajanhallinnan kysymykset uudella tavalla keskiöön. Vuoden 2018 Työolotutkimuksen mukaan haittaavan kiireen kokemus on lisääntynyt hälyttävässä määrin erityisesti naisten työssä (Sutela ym. 2019). Lisäksi korkeakoulutetut asiantuntijat kohtaavat työssään muita työntekijäryhmiä useammin erilaisia ajallisia haasteita (Väänänen ym. 2016).

Erilaiset ajanhallintavalmennukset ja -koulutukset ovat keino tukea asiantuntijoita ja asiantuntijatyöpaikkoja ajankäytön ongelmissa. Ajanhallinta onkin viime vuosina ollut suosittu työelämäkoulutusten ja itseapukirjallisuuden aihe (ks. esim. Allen 2015; Claessens ym. 2007).

Työpaikkojen henkilöstökoulutukset toteutetaan yhä useammin digitaalisesti. Vuonna 2018 palkansaajista 55 prosenttia oli kartuttanut osaamistaan verkkomateriaalin avulla, ylemmillä toimihenkilöillä osuus oli peräti 69 prosenttia (Lyly-Yrjänäinen 2019). Digitaalisilla koulutuksilla haetaan muun muassa joustavuutta ajasta ja paikasta, koulutusten skaalautuvuutta sekä kustannussäästöjä (esim. Means ym. 2014).

Tämä katsaus on arvio asiantuntijatyöhön suunnatusta ajanhallinnan verkkovalmennuksesta. Katsaus pohjautuu kolmessa asiantuntijaorganisaatiossa vuonna 2019 toteutettuihin valmennuksiin ja niistä kerättyihin arviointeihin.

\section{Ajanhallinnan määritelmästä ei yksimielisyyttä, ajanhallinnan interventiot usein yksilölähtöisiä}

Pyrkimystä ajan systemaattiseen käyttöön, eli ajanhallintaa, on tutkittu useilla tieteenaloilla, muun muassa sosiologiassa (ks. esim. Southerton 2003), psykologiassa (ks. esim. König \& Kleinmann 2007; Van Eerde 2015) ja käyttäytymistaloustieteessä (ks. esim. Soman 2001). Jos ajatellaan työelämää, aikaan ja sen hallintaan liittyvät kysymykset koskettavatkin useita työn ulottuvuuksia. (Työ)aikaa ja sen käyttöä on tarkasteltu esimerkiksi suhteessa työn ja yksityiselämän tasapainoon (Adam \& Jex 1999), työssä suoriutumiseen (Barling ym. 1996), stressiin (Häfner ym. 2014b) ja luovuuteen (Zampetakis 
ym. 2010). Yhtä, eri tieteenalat kattavaa määritelmää ajanhallinnalle ei kuitenkaan ole (Aeon \& Aguinis 2017).

Brad Aeon ja Herman Aguinis (2017) ovat pyrkineet syntetisoimaan eri tieteenalojen käsityksiä ajanhallinnasta. He lähestyvät ajanhallintaa näkökulmasta, jonka mukaan yksilöt ovat proaktiivisia, tarkoitushakuisia toimijoita, jotka tekevät jatkuvasti ajankäyttöönsä liittyviä päätöksiä (emt.), mutta joita samalla ohjaa ympäristön päätöksenteolle asettamat reunaehdot. Arvioinnin kohteena oleva valmennus nojaa Aeonin ja Aguiniksen (emt.) käsitykseen, jonka mukaan ajanhallinnalla viitataan päätöksentekoon, jolla yksilöt järjestävät ja sopeuttavat ajankäyttöään muuttuviin olosuhteisiin.

Työnantajat tarjoavat ajanhallinnan valmennuksia työntekijöilleen usein tarkoituksenaan lisätä yksilöiden tehokkuutta ja siten työyksiköiden tuottavuutta. Tarjolla olevien koulutusten ja kirjallisuuden näkökulma onkin usein varsin yksilökeskeinen. Esitellyissä tekniikoissa ei juuri huomioida tekijöitä, jotka ovat yksittäisen työntekijän vaikutusmahdollisuuksien ulkopuolella (vrt. Burt ym. 2010).

Työn ajallisen järjestyksen rakentuminen on kuitenkin sosiaalinen prosessi, jota yksilö voi harvoin yksin muuttaa tai hallita (Orlikowski \& Yates 2002; Claessens ym. 2007; Toivanen ym. 2016a; 2016b). Organisaation aikarakenteet vaikuttavat yksilöiden ajankäyttöön luomalla kehikon, jonka sisällä omaa ajankäyttöä järjestetään (Perlow 1999; Toivanen ym. 2016a). Aikaan liittyvät normit taas vaikuttavat ajankäyttöön yhteisesti jaettujen odotusten tai sääntöjen kautta, jotka tulevat erityisen näkyväksi silloin kun niitä rikotaan (Ancona ym. 2001).

Tämän katsauksen kohteena olevassa valmennuksessa ajankäytön sosiaalisen rakentumisen luonne on pyritty huomioimaan. Valmennuksen oppimateriaali avaa organisaatiotason käytäntöjen ja normien merkitystä ajankäytön säätelijänä sekä sisältää työyksikkökohtaisia tehtäviä yhteisten ajanhallintakeinojen kehittämisen tueksi.

\section{Ajanhallinnan interventioiden vaikutusten arviointi on vaikeaa ja tulokset epäselviä}

Ajanhallinnan ympärillä tehty tutkimus on keskittynyt tarkastelemaan ajanhallinnan interventioiden vaikutuksia hyvinvointiin ja työssä suoriutumiseen. Hyvinvoinnin osalta tutkimusten tulokset osoittavat ajanhallinnan potentiaalisesti lisäävän hyvinvointia ja vähentävän stressiä, tosin vaikutusten vahvuudessa on suurta vaihtelua. (Aeon \& Aguinis 2017.)

Työssä suoriutumisella ja ajanhallinnan interventioilla on monimutkaisempi suhde. Ajanhallinnan interventioiden vaikutus työssä suoriutumiseen silloin, kun termillä tarkoitetaan työn mitattavissa olevia tuloksia (kuten myyntiluvut, projektien valmiiksi saattaminen), on epäselvä (Aeon \& Aguinis 2017). Joissakin tapauksissa (esim. Claessens ym. 2004; Nonis ym. 2005) ajanhallintaa parantamaan pyrkivillä interventioilla on todettu olevan suotuisa vaikutus työssä suoriutumiseen. Toisaalta on näyttöä myös siitä (ks. esim. Häfner \& Stock 2010; Käser ym. 2013), että interventiot eivät ole parantaneet työssä suoriutumista mitattavissa olevien tulosten osalta.

Yksilön suoritusta voidaan tarkastella myös suorituskykyä edistävän käyttäytymisen ja siinä tapahtuneiden muutosten näkökulmasta (esim. Joo ym. 2017). Ajanhallinnalla onkin todettu olevan suotuisa yhteys luovuuteen (Zampetakis ym. 2010) ja ajanhallinnan tekniikoiden omaksumisen on todettu vähentävän viivyttelyä (van Eerde 2003; Häfner ym. 2014a).

Yksilöllinen vaihtelu aikaan liittyvissä asenteissa, uskomuksissa ja ajankäytön tavoissa on suurta. Tämä voi vaikuttaa kykyyn ja kiinnostukseen omaksua ajanhallinnan tekniikoita (esim. Vinton 1992). Esimerkiksi taipumus järjestelmälliseen työskentelytyyliin ja avoimuus uusien työskentelytapojen omaksumiselle voivat heijastua ajanhallinnan interventioiden tuloksiin (Claessens ym. 2007). Ajanhallinnan interventioiden vaikuttavuuden arviointi on hankalaa, koska on vaikea erottaa 
näitä luontaisia ominaisuuksia valmennuksen seurauksista.

Yhteenvetona voidaan todeta, että ajanhallinnan interventioiden vaikuttavuudesta on epäselvyyttä ja vaikuttavuuden arviointi on vaikeaa muun muassa yksilöiden välisten erojen takia. Tämän katsauksen kannalta kiinnostavaa on, että organisaatiotason aikarakenteiden ja normien merkityksen sivuuttaminen ajanhallinnan interventioissa on nähty yhdeksi syyksi siihen, miksi ne eivät suinkaan aina johda työsuorituksen parantumiseen (Jacobs \& Gerson 2004; Perlow 1999).

\section{Ajanhallinnan verkkovalmennus arvioinnin kohteena}

Arvioinnin kohteena oleva valmennus koostui viidestä verkossa suoritettavasta moduulista: 1. Aika ja erilaiset aikahaasteet työssä, 2. Priorisointi, 3. Työn näkyväksi tekeminen, 4. Keskeytysten hallinta ja 5. Mentaaliajanhallinta. Valmennuksen sisällön tuottamista on ohjannut Burtin ja kumppaneiden (2010) integroiva ajanhallinnan malli, joka huomioi Schriberin ja Gutekin (1987) tunnistamat ajankäytön hallinnan kannalta tärkeät tekijät: täsmällisyyden, prokrastinaation välttämisen, oman ajankäytön tiedostamisen ja suunnittelun, tehtävien priorisoinnin, aikatauluissa pysymisen, ajankäytön synkronoinin ja koordinoinnin sekä ajankäytön autonomisuuden kysymykset. Valmennus on mahdollista suorittaa täysin itsenäisesti tai työyksikkökohtaisesti fasilitaattorin tukemana.

Valmennus lähestyy ajankäytön ongelmia osin työyksikön yhteisesti ratkaistavina kysymyksinä. Tähän pyritään erityisesti valmennuksen työyksikkötasoisesti suoritettavassa versiossa, joka sisältää verkossa suoritettavia työyhteisön kehittämistehtäviä. Ne nostavat työyksikön ajankäytön ongelmat yhteiseen keskusteluun. Arvioinnin mielenkiinto kohdistui erityisesti työyksikkötasoisesti suoritettavaan valmennukseen.
Arvioinnin tavoitteena oli:

1) Arvioida valmennuksen vaikutuksia yksilöiden kokemiin aikahaasteisiin ja ajanhallinnan kokemukseen sekä hyvinvointiin.

2) Paikantaa ajanhallintaa parhaiten tukevia käytäntöjä ja tuottaa tietoa valmennuksen kehittämisen tueksi.

3) Arvioida, kuinka hyvin verkkovalmennus mahdollistaa työyhteisön yhteiseen kehittämiseen tähtäävän vuorovaikutuksen.

Arviointiin osallistui kolme asiantuntijatyöpaikkaa, joissa toteutettiin vuonna 2019 yhteensä neljä valmennusta. Valmennuksiin osallistui yhteensä 48 asiantuntijaa.

Aineistoa kerättiin seuraavasti:

- Kyselylomakkeella ennen valmennusta (osallistujien kokemat ajankäytön haasteet, töiden organisoinnin tavat, töihin keskittyminen, ajanhallinnan keinot, hyvinvointi ja palautuminen), $\mathrm{N}=36$

- Kyselylomakkeella välittömästi valmennuksen päätyttyä, $\mathrm{N}=22$

- Laadullisilla haastatteluilla valmennuksen päätyttyä, $\mathrm{N}=11$

- Kyselylomakkeella tammikuussa 2020, $\mathrm{N}=14$

Alku- ja loppukyselyissä käytettiin osin samoja mittareita kuin aikaisemmissa työaikoja koskevissa tutkimuksissa. Tutkimuksen kvantitatiivista aineistoa analysoitiin pääasiassa vertaamalla alku-ja loppukyselyjen prosenttiosuuksia. Kvalitatiivisen aineiston analyyttinen viitekehys perustuu laadullisen tutkimusotteen aineistolähtöiseen lähestymistapaan. Aineiston karkea teemoittelu toteutettiin sisällönanalyysin avulla. Seuraavassa alaluvussa käymme läpi arvioinnin tulokset ja esitämme tuloksista nousseita edellytyksiä onnistuneelle ajanhallinnan verkkovalmennukselle. 


\section{Yhteisesti tunnistettu tarve valmennukselle - edellytys sitoutumiselle}

Vaikuttavuutta arvioitaessa lähdetään usein liikkeelle tarpeesta, sillä toiminnan tavoitteet nousevat tarpeista käsin. Yksinkertaistetusti vaikuttavuustutkimuksissa koulutuksen vaikuttavuudella tarkoitetaan toiminnan tavoitteiden ja tehtävien täyttymistä. (Koskinen-Ollonqvist ym. 2005.) Ajanhallinnan valmennukseen osallistuvien työpaikkojen ja yksittäisten asiantuntijoiden tarve ja halu kehittää ajankäyttöä oli ilmeinen. Tämä tuli ilmi sekä alkukyselyssä että laadullisissa haastatteluissa.

Valmennuksen tavoitteena oli parantaa osallistujien ajankäytön hallintaa. Tavoitteen toteutumista arvioitiin muun muassa vertaamalla alkukyselyssä esiin tulleiden ajankäytön ongelmien tilannetta valmennuksen jälkeiseen aikaan. Tämä tarkastelu ei osoittanut merkittävää muutosta ajanhallinnan haasteiden osalta. Tulokset eivät myöskään viittaa siihen, että valmennukseeen osallistumisella olisi ollut vaikutuksia osallistujien hyvinvointiin tai palautumiseen.

Koettiinko valmennukseen osallistuminen siis hyödyttömäksi? Näin ei vaikuttaisi olevan, sillä laadullisen aineiston (haastattelujen ja kyselyjen avovastausten) perusteella valmennus koettiin monella tapaa hyödylliseksi ja lähes kaikki osallistujat suosittelisivat sitä asiantuntijatyötä tekeville. Miksi laadukkaaksi kuvattu valmennus, jonka kerrottiin "konkretisoineen sitä, mistä ongelmat johtuu" ja auttaneen "tunnistamaan ongelmia, joihin voi itse vaikuttaa ja niitä, jotka ovat yleisiä työelämässä" ei näy välittöminä muutoksina ajankäytön ongelmien ja hyvinvoinnin tasolla? Laadullisen aineiston tarkastelu antaa kiinnostavia viitteitä tästä.

\section{Ajanhallinnan ymmärtäminen yhteisen vastuun piiriin kuuluvaksi}

Laadullisesta aineistosta nousi esiin, että valmennukseen osallistuneet kokivat organisaa- tion käytäntöjen ja normien sekä työn luonteen pitkälti säätelevän omaa ajankäyttöään, kuten alla olevasta aineistokatkelmasta käy ilmi:

Aikataulutuksissa yms. harvoin kuunnellaan työntekijöitä. Se onko johonkin aikaa vai ei, lasketaan suoraan excelillä ja tämän mukaan mennään huolimatta siitä, mikä on kentän viesti.

Omaa ajankäytön hallintaa kuvattiin toteutettavan niissä puitteissa, jotka työn luonne ja työpaikan käytännöt mahdollistivat. Organisaation vahvaksi koettu rooli työn ajallisten olosuhteiden muokkaajana, ja siten myös ajankäytön ongelmien taustalla, heijastui osallistujien käsityksiin siitä, kenellä vastuun ajanhallinnasta kuuluisi olla:

Töitä on liikaa suhteessa tekijöihin. On ongelmallista jättää vastuu ajanhallinnasta vain työntekijälle, koska käytännössä se tarkoittaa, että joko laadusta tai määrästä tingitään ja lopulta työntekijä tekee päätöksen, kuinka toimii.

Sekä ennen että valmennuksen jälkeen kerätyssä aineistossa osallistujat artikuloivat ymmärtävänsä varsin selkeästi, että heillä on rajallinen kompetenssi täyttää kaikki työlle asetetut tavoitteet. Ajankäytön ongelmien nähtiinkin juontuvan suuremmissa määrin työn organisoinnista kuin omista työn tekemisen tavoista. Kysyttäessä, mitä vaikutuksia valmennuksella on ollut sinulle tai työyksiköllesi, useimmin toistunut vastaus oli, että valmennus auttoi tunnistamaan haasteita ja herätteli keskustelemaan. Valmennuksen vaikutusten uskottiin näkyvän jatkossa, jos asioita viedään yhdessä eteenpäin.

\section{Organisaation sitoutuminen kurssin tavoitteisiin ja työpaikan käytäntöjen kehittämiseen}

Erityisen selvää oli, että valmennukseen sitoutumista ja sen oppimistavoitteiden toteutumista olisi osallistujien mukaan tukenut työnantajan vahvempi sitoutuminen valmennuksen ta- 
voitteisiin. Yli puolet laadulliseen haastatteluun osallistuneista ilmaisi, että on työpaikasta ja sen johdosta kiinni, tulevatko valmennuksessa opitut asiat osaksi käytäntöjä:

Olisin kaivannut organisaatiolta enemmän sitoutumista valmennukseen ja ajankäytön ongelmien ratkaisemiseen.

Osa osallistujista koki työnanantajan sitoutumisen valmennukseen puutteelliseksi. Lisäksi joissakin aineistokatkelmissa esitettiin närkästystä herättänyt ajatus valmennuksesta työnantajan yrityksenä paikkailla ongelmaa haluamatta paneutua sen todellisiin syihin. Voikin kysyä, saattaako valmennuksella olla myös haitallisia vaikutuksia (ks. Aeon \& Aguinis 2017) erityisesti tilanteessa, jossa työn tavoitteet koetaan epärealistisiksi eikä työnantajan taholta ole tullut riittävää signaalia jakaa vastuuta ajankäytön ongelmien ratkaisuista.

Toisaalta osallistujien kokemus työnantajan sitoutumisesta ja valmennuksen vaikutuksista työyhteisössä vaihteli. Valmennuksen aikana tunnistettuihin epäkohtiin oli joidenkin osallistujien mukaan puututtu ja ratkaisuja myös viety käytäntöön. Kysyttäessä valmennuksen vaikutuksista työyhteisössä neljä kuukautta sen päättymisen jälkeen, kaksi eri henkilöä samalla työpaikalla vastasi seuraavasti:

Resurssivajeeseen on puututtu kovasti. Työuupuminen on otettu vakavasti. Työnantajan taholta priorisointia on terävöitetty. Näihin liittyvät ongelmat on tullut esiin ennen valmennuksen aloittamista, mutta valmennus on vahvistanut havaintoja.

En ole havainnut mitään muutosta.

Näin eriävät käsitykset alleviivaavat paitsi subjektiivisten kokemusten eroja, myös valmennuksen vaikutusten arvioinnin vaikeutta.

\section{Laadukkaat, eri formaateissa olevat, hyödyllisiä työkaluja sisältävät materiaalit}

Verkkovalmennusten vaikuttavuutta arvioineet tutkimukset (ks. esim. Means ym. 2014) ovat osoittaneet tekijöitä, joilla on myönteinen vaikutus oppimistuloksiin. Näitä ovat muun muassa monipuolinen, eri formaatteja hyödyntävä oppimateriaali ja opiskelun laadukas ohjaus. Nämä ovat myös tekijöitä, joiden on havaittu tukevan opiskelijoiden aktiivisuutta (Means ym. 2014). Valmennusta suunniteltaessa verkkovalmennusformaatin vahvuudeksi koettiin, että verkko-oppiminen yhdistää itsetutkiskelun ja (sitä ajallisesti seuraavan) työyhteisötason reflektion, joka ei edellytä välitöntä reagointia kuten kasvokkaiseen vuorovaikutukseen perustuvassa tilanteessa (esim. Vai \& Sosulski 2016).

Ajanhallinnan verkkovamennukseen osallistujat kokivat valmennuksen sopineen erityisesti omien ja työyksikön ajankäytön haasteiden tunnistamiseen. Hyödylliseksi koettiin myös erilaisten omaan työhön soveltuvien ajanhallinnan tekniikoiden esittely monipuoliseksi ja laadukkaaksi koetun materiaalin avulla.

Yhteiskehittämistehtäviin suhtauduttiin muuta materiaalia varautuneemmin. Niiden kuvattiin herättäneen keskustelua, mutta yli puolet haastatteluihin osallistuneista esitti toiveen kasvokkaisesta keskustelusta aiheiden tiimoilta. Verkossa tapahtunut vuorovaikutus ei siis kaikilta osin tyydyttänyt osallistujia:

Hyöty jää pieneksi, jos niistä asioista ei jutella tosielämässä. Työpaikka ei kehity, jos keskustelu ja ideointi käydään netissä, pitäisi istua pöydän äärelle vaikka harvemminkin.

Yhteiskehittäminen verkossa omien töiden lomassa ei kaikkien osallistujien mielestä toiminut, vaan työnantajan olisi toivottu sitoutuneen valmennukseen myös sille erikseen varatun ajan puitteissa. Lisäksi esimiehiltä toivottiin vahvempaa panosta yhteiskehittämistehtävissä syntyneen keskustelun yhteenvetämiseen ja keskusteluissa sovitun käytäntöön viemiseen. 


\section{Organisaation ja osallistujien yhteisesti tunnistama tarve valmennukselle}

$\rightarrow$ Sitoutumisen edellytys

Ajanhallinnan ymmärtäminen yhteisen vastuun piiriin kuuluvaksi

Edellytys sille, että asiantuntijan ajanhallinnan keinoille on organisaation tuki

Organisaation sitoutuminen kurssin tavoitteisiin ja työpaikan käytäntöjen kehittämiseen

$\rightarrow$ Välttämätöntä pysyvien muutosten aikaansaamiseksi

Laadukkaat, eri formaatteja hyödyntävät, hyödyllisiä työkaluja sisältävät materiaalit

$\rightarrow$ Edellytys aktiiviselle opiskelulle

\section{Kuvio 1. Onnistuneen ajanhallinnan verkkovalmennuksen edellytykset}

Tyytymättömyyttä verkossa tapahtuneeseen yhteiskehittelyyn selittää siis osin työnantajan puutteelliseksi koettu sitoutuminen. Tästä syystä on vaikea eritellä alustan merkitystä osittain epätyydyttäväksi koetun vuorovaikutuksen taustalla. Osallistujien vastaukset viittaavat kuitenkin siihen, että kasvokkaista vuorovaikutusta olisi arvostettu verkossa tapahtuvan vuorovaikutuksen rinnalla. Kuviossa 1 esitetään arvioinnista nousseet edellytykset onnistuneelle ajanhallinnan verkkovalmennukselle.

\section{Yhteenveto}

Ajanhallintaa on pidetty pääasiassa yksilön vastuun piiriin kuuluvana (Burt ym. 2010). Ajanhallintaan edistämään pyrkivien interventioiden ja niiden vaikutusta arvioineiden tutkimusten heikkouksiksi on katsottu organisaatiotason aikarakenteiden ja normien merkityksen sivuuttaminen (esim. emt; Jacobs \& Gerson 2004). Näistä puutteista kritisoineet huomauttavat (esim. Burt ym. 2010), että organisaatioympäristö voi toimia ajanhallinnan interventioissa välittävänä tekijänä siten, että ajankäy- tön hallinnan kannalta suotuisa ympäristö edesauttaisi myös yksilöitä omaksumaan ajanhallintaa edistäviä käytäntöjä.

Työelämävalmennusten vaikuttavuutta tutkineiden Traci Sitzmannin ja Justin Weinhardtin (2018) mukaan työntekijän sitoutuminen valmennukseen tapahtuu itselle merkitykselliseksi koettujen tavoitteiden muodostamisen ja niiden saavuttamisen priorisoinnin kautta. Tähän prosessiin liittyy sisäisiä ja ulkoisia - organisaatioympäristöön liittyviä - tekijöitä, jotka voivat edistää tai haitata toivottua käyttäytymisen muutosta. Organisaation koettu sitoutuminen valmennuksen tavoitteiden saavuttamiseen on keskeinen välittävä tekijä, joka vaikuttaa myönteisesti työntekijän omaan sitoutumiseen. (emt.)

Työntekijän on vaikea haastaa, saati muuttaa, organisaation aikaan liittyviä käytäntöjä (Burt ym. 2010; Toivanen ym 2016a). Ajanhallinnan valmennuksiin osallistuneille organisaation rooli ajankäytön säätelijänä oli selvä. Hyödylliseksi koetun valmennuksen vaikuttavuuden katsottiinkin, Siztmannin ja Weinhardtin (2018) käsityksiin sopien, riippuvan myös työnantajan sitoutumisesta valmennuksen tavoitteisiin. Valmennuksen arviointi 
vahvistaa näin ollen käsitystä siitä, että ajanhallinnan ongelmia ei ratkaista tukemalla vain yksilön ajankäytön hallintaa, vaan niiden ratkaisu edellyttää organisaatio- ja työyksikkötason sitoutumista.

Organisaation aikaan kytkeytyvät toimintatavat ja yhteiset aikarakenteet eivät muutu hetkessä. Arvioinnin kohteena ollut valmennus voidaan nähdä hyvänä alkuna pidemmälle kehittämisprosessille. Alati muuttuvassa ja kiivastahtisessa työelämässä haasteeksi nousee työpaikkojen sitoutuminen pitkäjänteiseen kehittämistyöhön.

\section{Kiitokset}

Katsauksen ykköskirjoittaja osallistui arvioinnin kohteena olevan Työterveyslaitoksen Aika \& fokus -verkkovalmennuksen kehittämiseen ja toimii sen valmentajana. Kiitämme NordForskia (hanke 74809) saamastamme tuesta sekä valmennukseen osallistuneita työpaikkoja ja asiantuntijoita.

\section{Kirjoittajat}

Kirsi Yli-Kaitala, VTM, erityisasiantuntija, Työterveyslaitos, sähköposti: kirsi.yli-kaitala@ttl.fi

Minna Toivanen, KM, vanhempi asiantuntija, Työterveyslaitos, sähköposti: minna.toivanen@ttl.fi

\section{Kirjallisuus}

Adams, G. \& Jex, S. (1999) Relationships between time management, control, work-family conflict, and strain. Journal of Occupational Health Psychology 4 (1), 72-77. https://doi.org/10.1037/1076-8998.4.1.72

Aeon, B. \& Aguinis, H. (2017) It's about time. New perspectives and insights on time management. Academy of Management Perspectives 31 (4), 309-330.

https://doi.org/10.5465/amp.2016.0166
Allen, D. (2015) Getting Things Done. The Art of Stress-Free Productivity. Lontoo: Piatkus.

Ancona, D., Okhuysen, G. \& Perlow, L. (2001) Taking time to integrate temporal research. Academy of Management Review 26 (4), 512-529.

https://doi.org/10.5465/amr.2001.5393887

Barling, J, Cheung, D. \& Kelloway, E. (1996) Time management and achievement striving interact topredict car sales performance. Journal of Applied Psychology 81 (6), 821-826. https://doi.org/10.1037/0021-9010.81.6.821

Burt, C., Weststrate, A., Brown, C. \& Champion, F. (2010) Development of the time management environment (TiME) scale. Journal of Managerial Psychology 25 (6), 649-668.

https://doi.org/10.1108/02683941011056978

Claessens, B., Van Eerde, W., Rutte, C. \& Roe, R. (2004) Planning behavior and perceived control of time at work. Journal of Organizational Behavior 25 (8), 937-950.

https://doi.org/10.1002/job.292

Claessens, B., van Eerde, W., Rutte, C. \& Roe, A. (2007) A review of the time management literature. Personnel Review 6 (2), 2550276. https://doi.org/10.1108/00483480710726136

Häfner, A., Oberst, V. \& Stock, A. (2014a) Avoiding procrastination through time management: An experimental intervention study. Educational Studies 40 (3), 352-360.

https://doi.org/10.1080/03055698.2014.899487

Häfner, A. \& Stock, A. (2010) Time management training and perceived control of time at work. Journal of Psychology 144 (5), 429-447. https:// doi.org/10.1080/00223980.2010.496647

Häfner, A., Stock, A, Pinneker, L. \& Ströhle, S. (2014b) Stress prevention through time management training intervention: An experimental study. Educational Psychology 34 (3), 403-416. https:// doi.org/10.1080/01443410.2013.785065

Jacobs, J. A., \& Gerson, K. (2004) The time divide: Work, family, and gender inequality. Cambridge, MA: Harvard University Press.

Joo, H., Aguinis, H. \& Bradley, K. (2017) Not all non-normal distributions are created equal: Improved theoretical and measurement precision. Journal of Applied Psychology 102 (7), 10221053. https://doi.org/10.1037/apl0000214

Koskinen-Ollonqvist, P., Pelto-Huikko, A. \& Rouvinen-Wilenius, P. (2005) Johdanto. Teoksessa P. Koskinen-Ollonqvist, A. Pelto-Huikko \& P. Rouvinen-Wilenius (toim.) Näkökulmia vaikuttavuu- 
teen. Vaikuttavuuden arvioinnin mahdollisuudet terveyden edistämisessä. Helsinki: Terveyden edistämisen keskus, 5-13.

Käser, P., Fischbacher, U. \& König, C. (2013) Helping and quiet hours: Interruption-free time spans can harm performance. Applied Psychology: An International Review 62 (2), 286-307. https:// doi.org/10.1111/j.1464-0597.2012.00517.x

König, C. J. \& Kleinmann, M. (2007) Time management problems and discounted utility. Journal of Psychology 141 (3), 321-334. https://doi.org/10.3200/JRLP.141.3.321-336

Lyly-Yrjänäinen, M. (2019) Työolobarometri 2018. Ennakkotiedot. Työelämä 15. Helsinki: Työ- ja elinkeinoministeriö.

Means, B., Bakia, M. \& Murphy, R. (2014) Learning Online. What Research Tells Us About Whether, When and How. New York \& Lontoo: Routledge. https://doi.org/10.4324/9780203095959

Nonis, S., Teng, J. \& Ford, C. (2005) A cross-cultural investigation of time management practices and job outcomes. International Journal of Intercultural Relations 29 (4), 409-428.

https://doi.org/10.1016/j.ijintrel.2005.05.002

Orlikowski, W. J. \& Yates J. A. (2002) It's about time: Temporal structuring in organizations. Organization Science 13 (6), 684-700.

https://doi.org/10.1287/orsc.13.6.684.501

Perlow, L. (1999) The time famine: Toward a sociology of work time. Administrative Science Quarterly 44 (1), 57-81. https://doi.org/10.2307/2667031

Schriber, J. \& Gutek, B. (1987) Some time dimensions of work: Measurement of an underlying aspect of organization culture. Journal of Applied Psychology 72 (4), 642-650.

https://doi.org/10.1037/0021-9010.72.4.642

Sitzmann, T. \& Weinhardt, J. (2018) Training engagement theory: A multi-level perspective on the effectiveness of work-related training. Journal of Management 44 (2), 732-756.

https://doi.org/10.1177/0149206315574596

Soman, D. (2001) The mental accounting of sunk time costs: Why time is not like money. Journal of Behavioral Decision Making 14 (3), 169-185. https://doi.org/10.1002/bdm.370

Southerton, D. (2003) Squeezing time: Allocating practices, coordinating networks and scheduling society. Time \& Society 12 (1), 5-25. https://doi. org/10.1177/0961463X03012001001

Sutela, H., Pärnänen, A. \& Keyriläinen, M. (2019) Digiajan työelämä - Työolotutkimuksen tuloksia 1977-2018. Helsinki: Tilastokeskus.

Toivanen, M, Viljanen, O. \& Turpeinen, M. (2016a) Aikamatriiseja asiantuntijatyössä. Työelämän tutkimus 4 (1), 77-94.

Toivanen, M, Yli-Kaitala, K, Viljanen, 0, Väänänen, A, Turpeinen, M, Janhonen, M. \& Koskinen, A. (2016b) Aikajärjestys asiantuntijatyössä. Helsinki: Työterveyslaitos.

Vai, M. \& Sosulski, K. (2016) Essentials of online course design: A standards-based guide. Toinen painos. New York: Routledge. https://doi.org/10.4324/9781315770901

Van Eerde, W. (2003) Procrastination at work and time management training. Journal of Psychology 137 (5), 421-434.

https://doi.org/10.1080/00223980309600625

Van Eerde, W. (2015) Time management and procrastination. Teoksessa M. D. Mumford \& M. Frese (toim.) The psychology of planning in organizations. Lontoo: Routledge, 312-333.

Vinton, D. (1992) A new look at time, speed, and the manager. Academy of Management Executive $6(4), 7-16$. https://doi.org/10.5465/ame.1992.4274427

Väänänen, A., Koskinen, A. \& Toivanen, M. (2016) Korkeakoulutetut asiantuntijat Suomessa. Teoksessa M. Toivanen, K. Yli-Kaitala, O. Viljanen, A. Väänänen, M. Turpeinen, M. Janhonen \& A. Koskinen Aikajärjestys asiantuntijatyössä. Helsinki: Työterveyslaitos, 21-30.

Zampetakis, L, Bouranta, N. \& Moustakis, V. S (2010) On the relationship between individual creativity and time management. Thinking Skills and Creativity 5 (1), 23-32. https://doi.org/10.1016/j.tsc.2009.12.001 